2018

\title{
Applying the Social Change Model of Leadership to an Entry-Level Occupational Therapy Doctorate Program
}

Lorry Liotta-Kleinfeld

Belmont University

Debra Gibbs

Belmont University

Yvette Hachtel

Belmont University

Teresa Plummer

Belmont University

Follow this and additional works at: https://encompass.eku.edu/jote

Part of the Occupational Therapy Commons

\section{Recommended Citation}

Liotta-Kleinfeld, L., Gibbs, D., Hachtel, Y., \& Plummer, T. (2018). Applying the Social Change Model of Leadership to an Entry-Level Occupational Therapy Doctorate Program. Journal of Occupational Therapy Education, 2 (1). https://doi.org/10.26681/

jote. 2018.020107 


\title{
Applying the Social Change Model of Leadership to an Entry-Level Occupational Therapy Doctorate Program
}

\begin{abstract}
Occupational therapy educators are tasked with preparing the future leaders in the profession. This responsibility requires a thoughtful and evidence based approach to reviewing and revising curricula to address changing professional and societal needs while aligning with a university's mission and vision. While the need for occupational therapy leadership has been a topic of much discussion in the literature, little has been written about evidence-based curricular practices to develop and prepare students for leadership roles. This article demonstrates how one entry-level occupational therapy doctorate program incorporated the underpinnings of the Social Change Model of Leadership Development (Wagner, 2006) into the curriculum. Curricular mapping and intentional learning experiences are described and doctoral student leadership outcomes are discussed.
\end{abstract}

Keywords

Curricular revision, Diamond Model, values, ethics

\section{Creative Commons License}

(c) (1) (3)

This work is licensed under a Creative Commons Attribution-Noncommercial-No Derivative Works 4.0 License.

\section{Acknowledgements}

The authors would like to acknowledge the faculty of the School of Occupational Therapy at Belmont University for their work with the curricular revision process. 


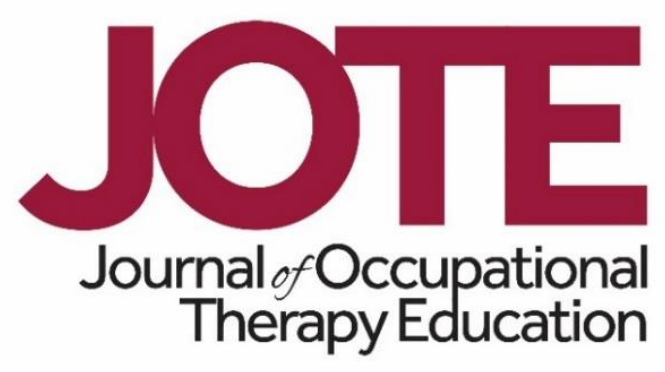

Volume 2, Issue 1

\title{
Applying the Social Change Model of Leadership to an Entry-Level Occupational Therapy Doctorate program
}

Lorry Liotta-Kleinfeld, EdD, OTR, BCP, FAOTA, Debra Gibbs, EdD, MHS, OTR/L,

CAPS, FAOTA, Yvette C. Hachtel, JD, MEd, OTR, FAOTA, and

Teresa Plummer, PhD, OTR/L, CAPS, CEAS, ATP

Belmont University

United States

\begin{abstract}
Occupational therapy educators are tasked with preparing the future leaders in the profession. This responsibility requires a thoughtful and evidence based approach to reviewing and revising curricula to address changing professional and societal needs while aligning with a university's mission and vision. While the need for occupational therapy leadership has been a topic of much discussion in the literature, little has been written about evidence-based curricular practices to develop and prepare students for leadership roles. This article demonstrates how one entry-level occupational therapy doctorate program incorporated the underpinnings of the Social Change Model of Leadership Development (Wagner, 2006) into the curriculum. Curricular mapping and intentional learning experiences are described and doctoral student leadership outcomes are discussed.
\end{abstract}

\section{INTRODUCTION}

The American Occupational Therapy Association (AOTA) Vision 2025 has emphasized the importance of leadership in occupational therapy and the need for occupational therapy leaders to be "influential in changing policies, environments, and complex systems" (AOTA, 2017b, para 4). Educators have a responsibility to develop students as leaders using effective practices of leadership development (Copolillo, Shepherd, Anzalone, \& Lane, 2010; Musselman, 2007). The current Accreditation Council of Occupational Therapy Educational Standards (ACOTE, 2011) require entry-level doctorate programs to prepare students beyond a generalist level in several areas including leadership. In addition, ACOTE (2017) has mandated that the entry-level 
degree for occupational therapists be at the doctorate level by 2027. Therefore, evidence-based curricular review is crucial for programs to address the standards as well as the profession's pressing need to develop leaders as effective change agents.

Belmont University is a private Christian university in the Southeastern United States that is home to an entry-level doctorate program in the School of Occupational Therapy (SOT). In 2014, an impending ACOTE self-study prompted the need for the SOT faculty to re-examine the curriculum design of the existing doctorate program. ACOTE (2011) Standard A.6.7 mandates that the curriculum design be based on the mission and philosophy of both the program and the institution. The SOT mission was for students to positively impact the community at large through meaningful and purposeful occupations (Belmont University, 2014). The university's mission was, in part, to empower men and women to engage and transform the world with disciplined intelligence, compassion, courage and faith (Belmont University, 2014). Both the SOT and university missions underscored the need to develop graduates who were sociallyresponsible, transformational leaders who served to address society's occupational needs and influence desirable social change. However, while preparing for the selfstudy, the university modified its strategic plan to include the expectation that learning to transform the world would occur through community service. Although one of the current SOT program themes was leadership, the SOT faculty now needed to reexamine leadership development to ensure that the program was adequately preparing community-focused and socially responsible leaders.

While the existing entry-level occupational therapy doctorate at Belmont University included an array of leadership experiences, including a didactic leadership course, a community service requirement, and discussions and reflections regarding leadership principles, these experiences were not guided by a comprehensive leadership development model. During the curricular review process, the faculty concluded that an evidence-based model was needed that would develop leaders as socially-responsible, change agents by establishing stronger threads between leadership, service, and scholarship.

Using the Diamond model (2008) to guide curricular review, it was determined that the Social Change Model (SCM) of Leadership Development (Wagner, 2006) was a comprehensive, well-researched model to guide leadership development. The SCM was developed in 1994 for use in higher education to develop student leadership competence (Astin \& Astin, 1996). Although used extensively by undergraduate leadership programs, few studies were found regarding the model's use in a graduate program and no literature was found regarding the application of this model in occupational therapy educational programs. The purpose of this paper is to describe the SCM and the method used to infuse this model in the occupational therapy doctorate curriculum at Belmont University. A secondary purpose is to discuss the appropriateness and relevance of the SCM model for entry level occupational therapy doctorate education. 


\section{CURRICULAR REVISION PROCESS: PHASE ONE}

\section{Diamond Model}

The occupational therapy faculty at Belmont University chose to incorporate aspects of Diamond's (2008) model to augment the curricular review process. The Diamond model is a data-driven, systematic model that can be used for evaluation of existing curricula and for curricular revision. The model consists of two phases. Phase one is the project selection and curricular design phase, whereas phase two is the production, implementation, and evaluation phase for each course in the program.

During the design phase, the need for "desirable" revision is identified. This is based on consideration of "inputs" including educational priorities, research, and societal needs. One educational priority was due to an increased focus at Belmont University on community service. This focus on community service provided further impetus to more purposefully develop socially-responsible leaders who are skilled at meeting society's occupational needs. The AOTA Centennial Vision (2007), which was the vision in existence at the time of the SOT program's self-study preparation, identified "preparing occupational therapists and occupational therapy assistants for the 21st century"; "meeting societal needs for health and well-being", and "linking education, research and practice" (p. 3) as strategic directions for the profession. The profession's vision also aligned with the SOT Mission and curricular threads of leadership, service, scholarship, and clinical excellence.

Identifying alignment with the educational priorities of the institution and the AOTA Centennial Vision, faculty turned to the literature to explore scholarly consensus regarding the need for leadership in occupational therapy and leadership development models used in higher education. Leadership development has long been a conversation among occupational therapy educators (Copolilo et al., 2010; Dunbar \& Winston, 2015; Fidler, 1996; Gilfoyle, 1989; Gitlow \& Flecky, 2005; Padilla, 2007; Peloquin, 2005). Several of these leaders have used the foundation of the Centennial Vision (Copolilo et al., 2010; Corcoran, 2005; Musselman, 2007; Padilla, 2007) to aver that leadership is a core construct to be imparted to students and practitioners. Leadership has been a topic included in several AOTA Presidential addresses and Eleanor Clark Slagle lectures including Gilfoyle (1989), Peloquin (2005), and Stoffel (2013). In her final presidential address, Gilfoyle (1989) stated that "leadership is the work of the leader, a leader who empowers others and serves for the good of the whole" (p. 567). In Stoffel's 2013 Inaugural Presidential Address, she suggested that the profession needs heartfelt leaders. She described heartfelt leaders as individuals who would be authentic and engender trust, commitment, and engagement. There was consensus that leadership is multifaceted and an essential trait, skill, and attitude of an occupational therapist. Intentional integration of the constructs and concepts necessary for leadership development appeared to be crucial to making a difference in the developmental process of students (Dugan \& Komives, 2007). Thus, occupational therapy education and curricula should be structured to develop and nurture graduates who are able and willing to assume leadership roles. 
Review of the ACOTE (2011) and World Federation of Occupational Therapy (WFOT, 2013) standards pertaining to leadership and leadership development revealed similar expectations. Twelve ACOTE Standards (B.7.1 to B.7.12) relate directly to Standard B.7 Leadership and Management. The WFOT Standards note that one purpose for having minimum standards is to educate therapists as leaders who are prepared to meet the daily challenges encountered in populations and societies locally and globally (WFOT, 2013). Although leadership performance criteria are identified in the ACOTE standards for doctoral programs and described in the WFOT standards, and considerable literature exists regarding the need for leadership in occupational therapy, little is written in the occupational therapy literature regarding theoretical models for leadership development in graduate occupational therapy programs.

\section{Social Change Model}

After an extensive literature search regarding leadership development models used in higher education, the SCM was identified as a viable model for the entry-level occupational therapy doctorate program at this university. The SCM approaches leadership as a "purposeful, collaborative, values-based process that results in positive social change" (Komives, Wagner, \& Associates, 2017, p. xiii). The model proposes that leadership is a process concerned with creating change on behalf of others and society. This model asserts that all students (not just those that hold formal leadership positions) are potential leaders and encourages highly participatory, non-hierarchical leadership. The model presents leadership development from three domains: the individual, group, and community/society. Each of these domains includes critical values for a total of seven Core Values, referred to as the $7 \mathrm{C}$ 's of leadership development. The individual values include consciousness of self, congruence, and commitment that are supportive of group functioning and positive social change. Group values of collaboration, common purpose, and controversy with civility indicate the processes needed to effectively work in groups to impact social change (Wagner, 2006). Citizenship, as a societal value, helps individuals become "responsibly connected to the community and to society through some activity" (Wagner, 2006, p.9). Some proponents of the model refer to change as an $8^{\text {th }} \mathrm{C}$, which is the desirable outcome based on the interaction and intersection of the C's (Dugan, 2006). Table 1 provides definitions of each of the values of the SCM as described by Astin and Astin (1996). 
Table 1

The Seven Core Values of the Social Change Model (7 C's)

\begin{tabular}{|l|}
\hline \multicolumn{1}{c|}{ Individual Values } \\
\hline $\begin{array}{l}\text { C1 Consciousness of Self: } \\
\text { Awareness of one's personal beliefs, values, attitudes, and emotions }\end{array}$ \\
\hline $\begin{array}{l}\text { C2 Congruence } \\
\text { actions }\end{array}$ \\
C3 Commitment \\
An intrinsic passion, energy, and purposeful investment toward collective \\
action. \\
\hline $\begin{array}{l}\text { C4 Collaboration } \\
\text { Group comes together, beyond individual values and ideas, capitalizing on each } \\
\text { individual's talents and diversity for creative solutions. }\end{array}$ \\
\hline $\begin{array}{l}\text { C5 Common Purpose } \\
\text { A shared responsibility towards collective aims, values, and vision. }\end{array}$ \\
\hline $\begin{array}{l}\text { C6 Controversy with Civility } \\
\text { Recognition that differences exist and must be aired openly with civility, respect } \\
\text { and willingness to hear all perspectives without criticism of others' views. }\end{array}$ \\
\hline $\begin{array}{l}\text { C7 Cocietal Values } \\
\text { Responsible connection to the community/society in which one resides by } \\
\text { actively working toward change to benefit others through care, service, social } \\
\text { responsibility, and community involvement. }\end{array}$ \\
\hline
\end{tabular}

Note. Adapted from Higher Education Research Institute (1996). A social change model of leadership development: Guidebook version III, p. 6-7. College Park, MD: National Clearinghouse for Leadership Programs. Reprinted with permission from Craig Slack, National Clearinghouse for Leadership Programs (NCLP).

The three clusters of core values (individual, group, and societal), are inextricably tied to each other creating "feedback loops" to enhance further development (Wagner, 2006, p. 9). For example, learning and development at the individual level helps facilitate the leadership process at the group level. Likewise, participation in collaborative group processes provides experience and feedback that enhances a person's development at the individual level. Figure 1 demonstrates the interaction between each of these three levels of values. Leadership is viewed as a group process, whereby individuals have developed a consciousness of self to better understand and interact with and on the 
behalf of others. This view of leadership fits with the diverse leadership needs of occupational therapy practitioners who work with individuals, groups, and communities in a variety of roles, practice areas, and settings. The roles may include evidence based clinician, educator, program developer, policy proponent, advocate, and researcher.

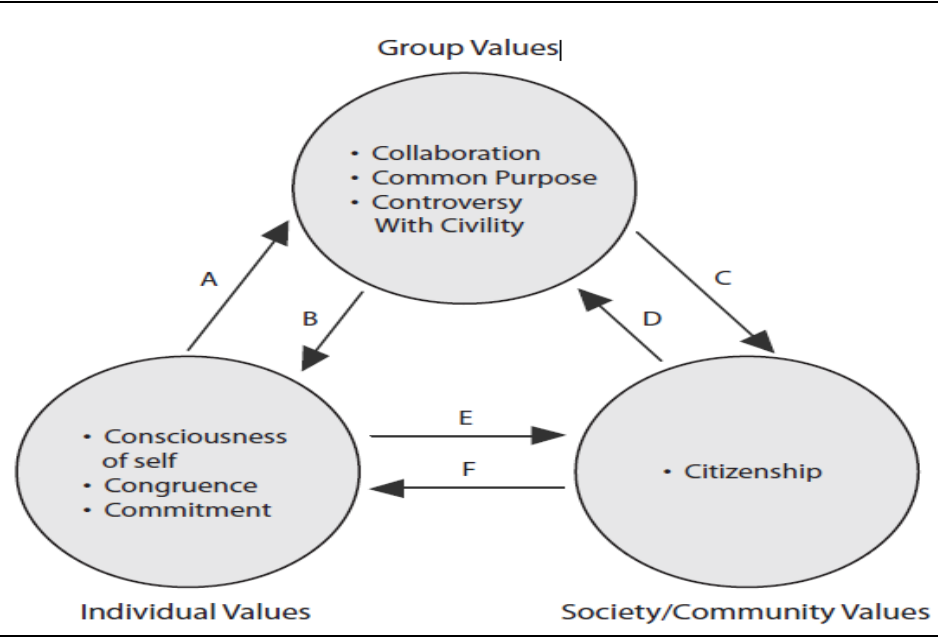

Figure 1. From Wagner, W. (2006). The social change model of leadership: A brief overview. Concepts \& Connections, 15 (1), 9. Reprinted with permission from Craig Slack, National Clearinghouse for Leadership Programs (NCLP).

Research on the SCM as it relates to undergraduate education is abundant. The MultiInstitutional Study for Leadership Development (MSL) first began reporting data in 2007 related to aspects of students' experiences associated with leadership outcomes (Dugan \& Komives, 2007). The MSL utilized the SCM as the core theoretical frame to study leadership development. The Socially Responsible Leadership Scale (SRLS) is a 103-item self-assessment instrument that measures the values associated with the SCM (Tyree, 1998). A reduced version of the SRLS, consisting of 68 items, was first administered to 50,378 undergraduate students from 52 campuses across the United States in 2006. The MSL research team also created items to assess students' perceptions of leadership efficacy. A major finding of the 2006 study was that experiences in college impacted perceived leadership efficacy as well as values associated with the SCM. Namely, Dugan and Komives (2007) found that experiences in college accounted for 7 to 14 percent of the overall variance in leadership outcomes with the greatest impact on citizenship (14\%), controversy with civility (11\%), and common purpose $(10 \%)$.

After completing several more research studies, the MSL published a leadership development report regarding predictors that were associated with shaping students' capacities for socially responsible leadership (Dugan, Kodama, Correia \& Associates, 2013). The purpose of the report was to focus on pedagogical considerations given the research findings. A major finding of the report was that although a multitude of experiences were examined, four experiences emerged that were considered "high impact practices" for leadership development. These practices included discussions about socio-cultural issues, mentoring by peers and/or faculty, participation in 
community service, and membership in off-campus organizations. These influences were found to influence leadership capacity across gender, race, and other demographic groups although the relative degree of the influence was found to vary somewhat based on demographics.

While research on the SCM as it relates to undergraduate education is abundant, research related to integration of this model in graduate or professional programs is scant. Iachini, Cross and Freedman (2015) discussed the results of infusion of the SCM into a graduate-level, social work single-course service learning component with structured reflection. In this study, students conducted program evaluations with community agencies to practice needs assessment as a leadership skill. Students reflected on the experience and the reflections were analyzed to examine how the "students interpreted and applied the SCM model as a whole, as well as interpreted and applied each of the seven specific values in the model" (p.657). Additionally, the community agencies were surveyed to determine their perspective and satisfaction. The values of consciousness of self, collaboration, and controversy with civility were described the most by students. In contrast, the values of commitment, congruence, and citizenship values were the least described. The researchers concluded that the learning experience may have been most conducive to develop students' understanding of group dynamics including challenges and benefits of collaborative work. The research findings supported the reciprocal benefit of a community service project to promote student learning while simultaneously benefitting the community.

Before a final decision was made to adopt the SCM as part of the Belmont occupational therapy doctorate program's curricular design, faculty reviewed the model to determine if there was congruency among the SCM values, the university's mission and vision, and the professions' values and ethical principles (AOTA, 2015). Examples of alignment are demonstrated in Table 2; bolded words indicate words or concepts of similar meaning among the four categories. 
Table 2

Examples of Alignment of Values among the Social Change Model, Belmont University Mission/Vision, and Occupational Therapy Core Values and Ethics

\begin{tabular}{|c|c|c|c|}
\hline $\begin{array}{l}\text { Social Change } \\
\text { Model's } \\
\text { Focus and Values }\end{array}$ & $\begin{array}{l}\text { Belmont University's } \\
\text { Mission and Vision }\end{array}$ & $\begin{array}{l}\text { Core Values of } \\
\text { Occupational } \\
\text { Therapy* }\end{array}$ & $\begin{array}{l}\text { Examples of Ethical } \\
\text { Principles and } \\
\text { Standards of } \\
\text { Conduct from AOTA } \\
\text { Code of Ethics* }\end{array}$ \\
\hline $\begin{array}{l}\text { "Leadership" is } \\
\text { concerned with } \\
\text { effecting change on } \\
\text { behalf of others } \\
\text { and society. } \\
\text { The model explicitly } \\
\text { promotes the values } \\
\text { of equity, social } \\
\text { justice, self- } \\
\text { knowledge, personal } \\
\text { empowerment, } \\
\text { collaboration, } \\
\text { citizenship, and } \\
\text { service. }\end{array}$ & $\begin{array}{l}\text { Empower men and } \\
\text { women of diverse } \\
\text { backgrounds to } \\
\text { engage and } \\
\text { "transform" the } \\
\text { world with } \\
\text { disciplined } \\
\text { intelligence, } \\
\text { compassion, } \\
\text { courage and faith. } \\
\text { University Vision } \\
\text { 2015 is to become } \\
\text { the best in the world } \\
\text { at engaging our } \\
\text { students in service } \\
\text { learning, } \\
\text { internships, and } \\
\text { community } \\
\text { service. }\end{array}$ & $\begin{array}{l}\text { Altruism } \\
\text { Equality } \\
\text { Freedom } \\
\text { Justice } \\
\text { Dignity } \\
\text { Truth } \\
\text { Prudence }\end{array}$ & $\begin{array}{l}\text { Principle 4D: } \\
\text { Advocate for } \\
\text { changes to systems } \\
\text { and policies that are } \\
\text { discriminatory or } \\
\text { unfairly limit or } \\
\text { prevent access to } \\
\text { OT services. } \\
\text { Principle 6H: } \\
\text { Promote } \\
\text { collaborative } \\
\text { actions and } \\
\text { communication as a } \\
\text { member of inter- } \\
\text { professional } \\
\text { teams... } \\
\text { Principle 4B: } \\
\text { Assist those in } \\
\text { need of OT services } \\
\text { in securing access. } \\
\text { Principle 3D: } \\
\text { Establish a } \\
\text { collaborative } \\
\text { relationship with } \\
\text { recipients of } \\
\text { service...to promote } \\
\text { shared decision } \\
\text { making. }\end{array}$ \\
\hline
\end{tabular}

${ }^{\star}$ From: American Occupational Therapy Association. (2015). Occupational therapy code of ethics. American Journal of Occupational Therapy, 69, 6913410030p1-

6913410030p8. https://doi:10.5014/ajot.2015.696S03 
Faculty also examined the seven core constructs (C's) of the SCM in relation to the existing curriculum design. The existing curriculum design was based on Caffarella and Daffron's (2013) Program Planning Model and Tyler's (2013) objective oriented view of education. Caffarella and Daffron's belief that the purpose of education is to encourage growth, to assist with change for desired results, and to examine community and social issues was found to complement the core constructs of the SCM. In addition, student outcomes were examined to determine if student development based on the SCM values would support the desired learning outcomes. Table 3 depicts two of the seven doctoral student learning outcomes mapped to the program themes of leadership, service, clinical excellence, and scholarship along with the SCM core values, as well as doctoral courses and curricular requirements. For purposes of brevity only a sampling of courses and curricular requirements were included in the chart. Note that the occupational therapy doctoral program experiential component (EC) and the program outcomes related to ethics, standards, values, and attitudes of the occupational therapy profession require the student to utilize all the values of the SCM.

Table 3

Doctoral Student Learning Outcomes Mapped to Program Themes and Values of the Social Change Model

\begin{tabular}{|c|c|c|c|}
\hline Student Learning Outcome & $\begin{array}{l}\text { SCM } \\
\text { Values* }\end{array}$ & $\begin{array}{l}\text { Program } \\
\text { Themes }\end{array}$ & $\begin{array}{l}\text { Courses } \\
\text { And Curricular Requirements }\end{array}$ \\
\hline $\begin{array}{l}\text { Students will uphold the } \\
\text { ethical standards, values } \\
\text { and attitudes of the } \\
\text { occupational therapy } \\
\text { profession. }\end{array}$ & C1-7 & $\begin{array}{l}\text { Leadership } \\
\text { Service } \\
\text { Clinical } \\
\text { Excellence } \\
\text { Scholarship }\end{array}$ & $\begin{array}{ll}\text { - } & \text { Ethics Course } \\
\text { - } & \text { Group Dynamics Course } \\
\text { - } & \text { Servicention Courses } \\
\text { - } & \text { Advising for Professional } \\
& \text { Behavior } \\
\text { - } & \text { Level I fieldwork } \\
\text { - } & \text { Level II fieldwork } \\
\text { - } & \text { Experiential Component }\end{array}$ \\
\hline $\begin{array}{l}\text { Demonstrates advanced } \\
\text { skills (clinical practice, } \\
\text { research, administration, } \\
\text { leadership, program and } \\
\text { policy development, } \\
\text { advocacy, education or } \\
\text { theory development, those } \\
\text { beyond a generalist) } \\
\text { through the completion of } \\
\text { the experiential component. }\end{array}$ & C1-7 & $\begin{array}{l}\text { Leadership } \\
\text { Service } \\
\text { Clinical } \\
\text { Excellence } \\
\text { Scholarship }\end{array}$ & $\begin{array}{l}\text { Embedded in specific doctoral } \\
\text { courses (such as } \\
\text { Cognitive/Perception, } \\
\text { Instructional Strategies, } \\
\text { Technology and Environmental } \\
\text { Interventions II, Research II, } \\
\text { Leadership and Public Policy) } \\
\text { - Experiential Component }\end{array}$ \\
\hline
\end{tabular}


Once the student learning outcomes, program themes, courses, and curricular requirements were mapped to the constructs of the SCM, the curricular sequence was re-examined based on the recommended process of leadership development as outlined by the theoretical underpinnings of the SCM. Individual, group, and societal/ community values are presented through all semesters of the program. Individual values are, however, emphasized early in the program, followed by group values then society/community values. This pedagogical approach was supported by MSL's 2012 analysis of leadership data (Dugan et al., 2013). The MSL reported that leadership development based on SCM values may be more developmental and linear than previously thought (p. 26). This sequence is used to enable students to actualize the SCM values during their Level II fieldwork and the EC. See Figure 2 for an overview of the SCM values within the curriculum.

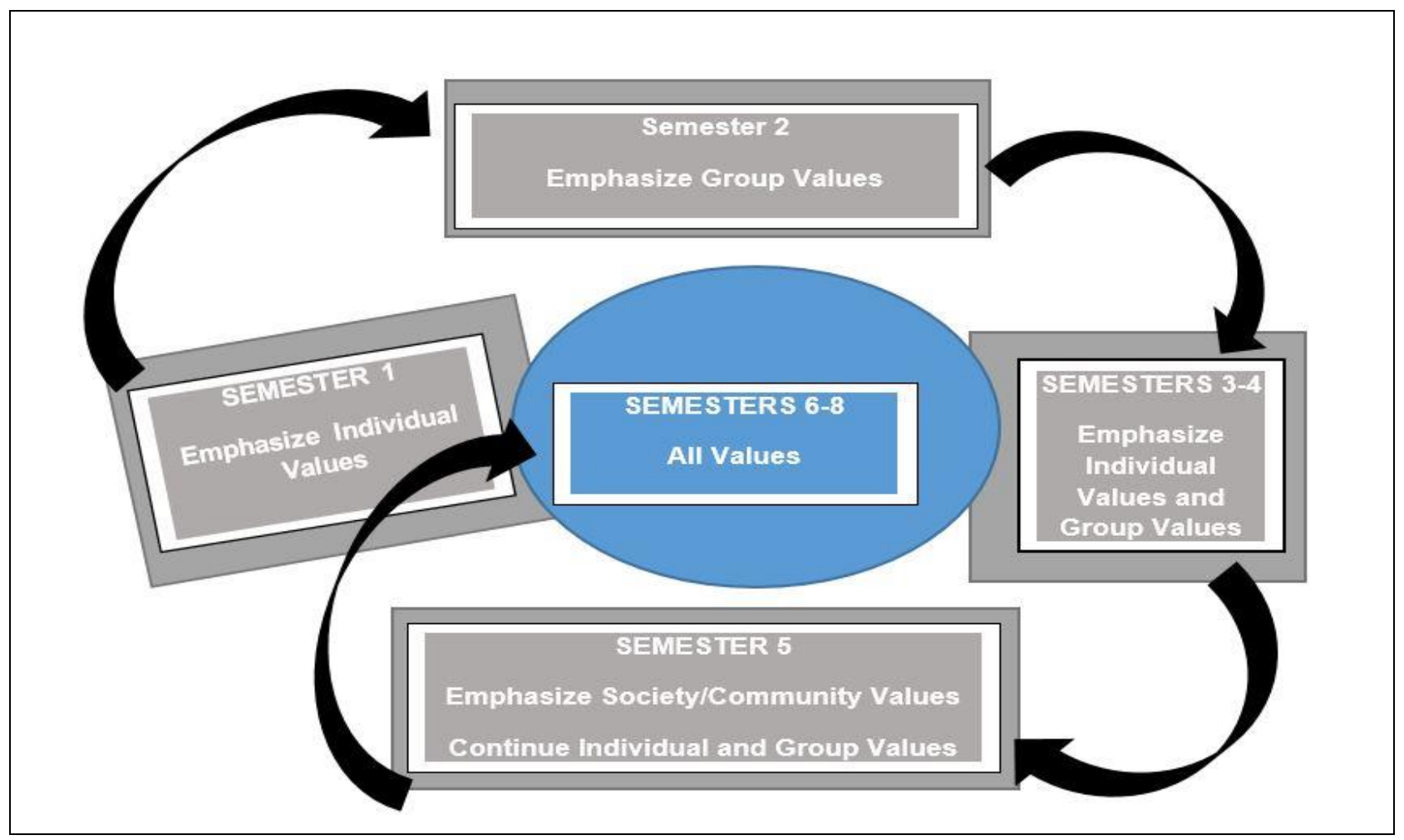

Figure 2. Illustration of the infusion of SCM values within the curricular sequence.

Once the overall sequence was determined, each semester was examined to embed experiences consistent with SCM values and to incorporate high impact practices of leadership development. In the first semester, the individual values of the SCM are emphasized as students engage in the high impact practice of mentoring as well as relevant coursework and service experiences. Development of consciousness of self is one of the focal points of this semester's leadership development. All students are assigned a faculty advisor who meets with students twice per semester for mentoring. A mentor is "a person who intentionally assist[s] the student's growth or connects the student to opportunities for career or personal development" (Dugan et al., 2013, p.10). 
Advisement fosters reflection regarding gaps in learning as well as the skills needed to fulfill the role as future change-agents and advocates for both the profession and individuals who may benefit from occupational therapy services. In MSL's 2006 study, the high impact practice of faculty mentoring was "one of the top three predictors of a higher score across all SCM values with the exception of Citizenship and Collaboration" (Dugan \& Komives, 2007, p. 15). In preparation for the mentoring session, students complete the program's professional behavior self-assessment that is based on Fidler's work (1996). The professional behavior assessment was mapped to the SCM values by Belmont faculty so that clear ties were apparent between leadership values and professional behaviors. A sample of professional behaviors linked to the values (C's) of the SCM is highlighted in Table 4. The student's professional behavior growth is expected to occur in a developmental fashion and the criteria reflect this expectation. The professional behavior criteria are used by the student and faculty advisor for assessment, discussion and goal setting.

Table 4

Professional Behaviors Assessment Examples and Linkage to the Values (C's) of Social Change Model

\begin{tabular}{|c|c|c|c|c|c|}
\hline SCM Value & $\begin{array}{c}\text { Professional } \\
\text { Behavior } \\
\text { Criteria }\end{array}$ & Insufficient & In progress & $\begin{array}{c}\text { Meets } \\
\text { expectations }\end{array}$ & $\begin{array}{c}\text { Exceeds } \\
\text { expectations }\end{array}$ \\
\hline $\begin{array}{l}\text { C2 } \\
\text { Congruence }\end{array}$ & $\begin{array}{l}\text { Ethical } \\
\text { Behavior }\end{array}$ & $\begin{array}{l}\text { Student } \\
\text { does not } \\
\text { demonstrate } \\
\text { an awareness } \\
\text { of the Code of } \\
\text { Ethics or } \\
\text { violates } \\
\text { professional } \\
\text { Code of } \\
\text { Ethics. }\end{array}$ & $\begin{array}{l}\text { Student } \\
\text { demonstrates } \\
\text { knowledge of } \\
\text { code of ethics } \\
\text { and an } \\
\text { awareness of } \\
\text { how the code } \\
\text { may affect } \\
\text { clinical } \\
\text { situations. }\end{array}$ & $\begin{array}{l}\text { The student } \\
\text { adheres to } \\
\text { ethical } \\
\text { principles in } \\
\text { classroom } \\
\text { and clinical } \\
\text { environments } \\
\text { and } \\
\text { demonstrates } \\
\text { an applied } \\
\text { understand- } \\
\text { ing of the } \\
\text { Code of } \\
\text { Ethics. }\end{array}$ & $\begin{array}{l}\text { Consistently } \\
\text { demonstrates } \\
\text { ethical } \\
\text { behavior and } \\
\text { demonstrates } \\
\text { a depth of } \\
\text { understand- } \\
\text { ing of ethical } \\
\text { behavior in a } \\
\text { broad variety } \\
\text { of situations. }\end{array}$ \\
\hline $\begin{array}{l}\text { C4 } \\
\text { Collaboration }\end{array}$ & Group Work & $\begin{array}{l}\text { Student does } \\
\text { not } \\
\text { demonstrate } \\
\text { the ability to } \\
\text { work with } \\
\text { others in } \\
\text { groups or } \\
\text { teams utilizing }\end{array}$ & $\begin{array}{l}\text { Student has } \\
\text { difficulty in } \\
\text { several key } \\
\text { behaviors for } \\
\text { effective } \\
\text { team/group } \\
\text { work requiring } \\
\text { guidance from }\end{array}$ & $\begin{array}{l}\text { Student } \\
\text { demonstrates } \\
\text { the ability to } \\
\text { work with } \\
\text { others in } \\
\text { groups or } \\
\text { teams utilizing } \\
\text { effective }\end{array}$ & $\begin{array}{l}\text { Student } \\
\text { consistently } \\
\text { demonstrates } \\
\text { active and } \\
\text { independent } \\
\text { ability to work } \\
\text { with others in } \\
\text { groups or }\end{array}$ \\
\hline
\end{tabular}




\begin{tabular}{|c|c|c|c|c|}
\hline $\begin{array}{l}\text { C6 } \\
\text { Controversy } \\
\text { with civility }\end{array}$ & $\begin{array}{l}\text { effective } \\
\text { interpersonal } \\
\text { and } \\
\text { behavioral } \\
\text { strategies to } \\
\text { attain a } \\
\text { common } \\
\text { purpose. }\end{array}$ & $\begin{array}{l}\text { faculty to } \\
\text { identify and } \\
\text { implement } \\
\text { effective } \\
\text { interpersonal } \\
\text { and } \\
\text { behavioral } \\
\text { strategies to } \\
\text { attain a } \\
\text { common } \\
\text { purpose. }\end{array}$ & $\begin{array}{l}\text { interpersonal } \\
\text { and } \\
\text { behavioral } \\
\text { strategies to } \\
\text { attain a } \\
\text { common } \\
\text { purpose with } \\
\text { limited } \\
\text { guidance } \\
\text { required. }\end{array}$ & $\begin{array}{l}\text { teams utilizing } \\
\text { effective } \\
\text { interpersonal } \\
\text { and } \\
\text { behavioral } \\
\text { strategies to } \\
\text { attain a } \\
\text { common } \\
\text { purpose. } \\
\text { Establishes } \\
\text { and maintains } \\
\text { cooperative } \\
\text { working } \\
\text { relationship } \\
\text { with others. } \\
\text { Approaches } \\
\text { tasks with } \\
\text { confidence } \\
\text { and a positive } \\
\text { attitude } \\
\text { (smiles when } \\
\text { working, sees } \\
\text { the best in } \\
\text { situations). }\end{array}$ \\
\hline
\end{tabular}

Another avenue for professional behavior development that is initiated the first semester is participation in inter-professional education events. These events afford opportunities for expansion of personal awareness while also facilitating team responsibility and collaboration that are related to group values of the SCM.

In an orientation experience to service during the first semester, students have the opportunity to serve a community agency with mentoring provided by a faculty member and returning students. The experience involves both faculty and peer mentoring. The service experience includes debriefing with the students to facilitate reflection on the impact of service related to consciousness of self as well as the potential benefit to the agency. Threaded throughout the curriculum, the student is required to complete a minimum of four service hours each semester. Students identify gaps in their service history through self-assessment and self-reflection as they begin developing their understanding of populations, and occupational justice.

A service and scholarship plan (see Appendix $A$ ) is completed by each student in consultation with the student's academic advisor. Faculty advisors provide mentoring to guide students to engage in a wide array of service activities with differing populations and in differing contexts for a well-rounded educational experience. Students complete reflections with each service experience to develop their self-awareness as a leader and 
to enhance knowledge of community agencies' needs and issues impacting population health and wellness. Student reflections are reviewed to ensure students are constructing meaning from their experiences. The reflections are also examined for scaffolding or comparing current experience to previous learning experiences.

Dugan and Komives (2007) state that service opportunities must reflect the values of the leadership constructs being taught, involve students working directly with individuals and communities, include critical reflection about the service, and allow students to apply their leadership learning in the "real world." In other research, Tyree (1998) identified that service had a moderate effect size on leadership outcomes with subsequent regression analysis showing the strongest influence on the SCM values of citizenship and collaboration.

An effective leader uses evidence to improve practice (Stetler, Ritchie, Rycroft-Malone, \& Charns, 2014). Population exposure and service support the students' future scholarly endeavors and professional responsibility in using literature to inform practice. This is formalized by requiring students to complete a curriculum wide literature matrix to explore, analyze, and synthesize current evidence and best practices in relation to individual and population needs. Students also reflect on their personal values, knowledge of populations as well as population needs, and skills of scholarship during advising with their faculty mentor. During the mentoring sessions, scholarly opportunities often emerge for the development of the student's EC. For example, a student may develop a research or EC project to investigate or address a societal problem which is consistent with the scholarship of application as identified in the Boyer Model of Scholarship (1990). Thus, service, scholarship, and leadership are explicitly linked.

Consistent with the recommended sequence of the SCM as noted by Dugan et al., (2013), the second semester continues to build on individual and society/community values while emphasizing the group values of the SCM through continued service, clinical courses and engagement in the first of three Level I fieldwork experiences. The Level I fieldwork experience requires a minimum of 60 hours of experience that provides further exposure to populations and settings as well as occupational therapy practices. Students are provided feedback from clinicians regarding professional behaviors such as taking personal responsibility (SCM value of consciousness of self), having a "team player" attitude (SCM value of collaboration and common purpose), flexibility, and professional communication skills (SCM value of controversy with civility). Each of the three Level I fieldwork experiences also include a seminar experience which includes discussion of personal values. A discussion of socio-cultural issues is also purposively integrated and facilitated.

The high impact practice of discussions regarding socio-cultural issues (Dugan et al., 2013) is facilitated by several lectures on occupational justice, structural competence, implicit/explicit bias, and discrimination. Discussion includes an exploration of power structures, power differences, and consideration of these issues to systems of oppression. 
In the third and fourth semesters students continue to explore individual and group values, although societal and community values are not overlooked. Students delve into their role as future leaders in courses on leadership and management. Students identify and adapt existing management models or develop new service provision models to respond to societal needs and emerging practice areas. Students explore a variety of leadership models, program development, program evaluation, and business proposals as they develop a personal vision statement and complete personal leadership assessments. Additionally, faculty mentors guide the planning and design of an EC that builds upon the student's personal vision statement, population, and agency experiences. Agency and external expert mentor contacts with demonstrated expertise in the student's focused area of study are identified. Consistent with the SCM, all parties begin a discussion to align the students' values with the needs of the community agency and the population it serves. This is another example of the high impact practice of mentoring as identified by Dugan et al. (2013).

The fifth semester focuses on societal and community values. Students are provided experiences to build greater awareness of the professional role in community based settings. Student experiences support leadership as a collaborative effort as they are exposed to transdisciplinary, multidisciplinary, and interdisciplinary practices. Students continue their collaboration with faculty, expert mentors, and community agencies to develop individual learning goals to support advanced practice (clinical, research, administration, leadership, program and policy development, advocacy, education, or theory development) while addressing a societal/ community need in preparation for their EC.

During the sixth and seventh semester students transition from the classroom to a practice setting through participation in Level II fieldwork. These experiences allow the students to express and operationalize all values of the SCM within a practice environment. Under the supervision of practicing clinicians and faculty, students are given feedback for continued professional behavior growth and professional enculturation.

In the final semester, students actualize all values of the SCM, including the value of "change", as they work collaboratively with a faculty mentor, expert mentor, a community agency, and a population to create positive social change. This experience is a realization of the student's leadership development that has occurred through the five didactic academic semesters, practiced during Level II fieldwork experiences (sixth and seventh semester) and honed and exercised through guidance of faculty and community experts.

\section{CURRICULAR REVIEW PROCESS: PHASE TWO}

Once the course sequence was finalized based on SCM values, phase two of the Diamond model was followed to review course objectives, instructional methods, learning experiences, and assessment measures with additional specificity to ensure alignment with SCM values and attainment of student learning outcomes. The course objectives and/or ACOTE Standards on each course syllabi were examined to 
determine their potential relationship to SCM values. As appropriate, the relevant SCM values were added next to the course objective. Table 5 provides an example of the relationship between ACOTE Standards/Course Objectives, SCM values, and learning activities for two courses that are offered during the program.

Table 5

Example of Relationship Between ACOTE Standard/Course Objectives, Learning Activities, and SCM values

\begin{tabular}{|l|l|l|}
\hline $\begin{array}{l}\text { ACOTE Standards/Course } \\
\text { Objectives }\end{array}$ & $\begin{array}{l}\text { Social } \\
\text { Change } \\
\text { Values (7 } \\
\text { C's) }\end{array}$ & Learning Activity (course level) \\
\hline $\begin{array}{l}\text { Develop occupation based } \\
\text { intervention plans based on } \\
\text { client needs and data from } \\
\text { evaluation process in } \\
\text { collaboration with client and } \\
\text { others. Plan must be culturally } \\
\text { relevant and reflect current OT } \\
\text { practice. } \\
\text { (B.5.1) }\end{array}$ & $\begin{array}{l}\text { Group C5: } \\
\text { Common } \\
\text { Purpose }\end{array}$ & $\begin{array}{l}\text { Students are given a scenario to } \\
\text { create a client centered group } \\
\text { intervention plan based on the } \\
\text { stated needs, values and cultural } \\
\text { background of the clients. The } \\
\text { plan must be reflective of current } \\
\text { occupational therapy practice and } \\
\text { be supported by available } \\
\text { evidence. }\end{array}$ \\
\hline $\begin{array}{l}\text { Demonstrate strategies for } \\
\text { analyzing issues and making } \\
\text { decisions to resolve personal } \\
\text { and organizational ethical } \\
\text { conflicts. } \\
\text { (B.9.10) }\end{array}$ & $\begin{array}{l}\text { Group C6: } \\
\text { Controversy }\end{array}$ & $\begin{array}{l}\text { Through participation in a mock } \\
\text { mediation, demonstrate problem- } \\
\text { solving by utilizing an ethical } \\
\text { decision-making model, identify } \\
\text { personal values that might impact } \\
\text { your decision, generate a list of } \\
\text { possible solutions, and document } \\
\text { the rationale for arriving at your } \\
\text { final decision to best resolve } \\
\text { personal and organizational } \\
\text { ethical conflict. }\end{array}$ \\
\hline
\end{tabular}

In addition to course specific evaluation measures related to attainment of specific course objectives and SCM values, non-course related curricular evaluation measures were also finalized. Additional formative and summative evaluation measures consistent with the SCM were considered and adopted. Measures that are geared to assess a student's growth in the area of individual values are implemented early in the program whereas evaluation measures that focus on development related to group and societal values are emphasized to a greater extent towards the end of the program. Some of the 
non-course related evaluation measures are the previously described service and scholarship plan and professional behavior assessment in addition to administration of the SLRS (Tyree, 1998) and the EC assessment.

The SRLS (Tyree, 1998) is administered four times during the course of the doctoral program; twice in the first semester (at the beginning and at the end of the first semester), a third time at the end of all academic coursework but before Level II fieldwork experiences, and finally at the completion of the program. Komives and Wagner (2017) state that the SLRS can be administered before and after an educational experience or program to evaluate student growth and development related to leadership skills. Assessing leadership development affords educators the ability to not only ascertain student change in leadership over time, but enables the program to evaluate effectiveness of educational experiences and obtain information for program development. The data is currently being analyzed from the first cohort of students who have completed the survey four times.

The EC evaluation is a multi-faceted summative evaluation. It consists of an evaluation of the implementation of an individualized learning plan along with the following: a personal vision statement, an application of evidence paper, four reflections, a time log, artifacts of the work product, an electronic poster, and the student's curriculum wide literature matrix representing the students' integration of evidence based practice, and exploration of various sociopolitical, geographical and environmental issues facing individuals.

\section{OUTCOMES}

Outcomes related to incorporation of the SCM can best be exemplified with student examples. In a service opportunity, spearheaded by a faculty mentor, one doctoral student found his passion in working with children with disabilities by volunteering at an event for modifying ride on toys. This student continued to pursue his interest in the area of assistive technology and addressing the needs of wheelchair users. He was mentored in locating additional service opportunities with multiple agencies that provide recreational and fitness opportunities for wheelchair users. This student continued to build his experiences by completing a Level II fieldwork rotation with an occupational therapist who was also a wheelchair supplier and Assistive Technology Professional. The doctoral program fostered a leadership opportunity for the student to serve as Leadership Delegate from the doctoral program at a leadership health care event in Washington, D.C. The student completed a comprehensive literature review and engaged in action research related to early wheeled mobility for his EC. As part of his $E C$, this student's faculty mentor facilitated an opportunity for this student to present at the International Seating Symposium and the AOTA annual conference. Additionally, a single subject case study of a child who received a ride on toy is in progress for journal submission. The combination of experiences helped this student develop advanced practice skills. Based on his specialized knowledge, this highly motivated graduate was recruited by a university that specializes in mobility related research. A position was created for him to serve in the role of clinician, researcher, and presenter. This example illustrates the impact of service involvement on the development of scholarship and 
clinical excellence. This is also consistent with the Centennial Vision of "linking education, research and practice" (AOTA, 2007, p.3). In addition, the high impact and recommended practices of leadership development by Dugan et al. (2013), including participation in community service, campus involvement in leadership experiences, mentoring by faculty, and attainment of a formal leadership position, are evident.

During her first semester, another student identified an interest in working with elementary aged children in a community and/or educational setting on her service and scholarship plan. Subsequently, the student developed a vision of working in pediatrics due to her continued reflection on her individual values. To pursue her interest in activities to promote social participation of children with disabilities, the student completed one of her curricular service requirements by volunteering as a cheerleading coach for a group of young females who are wheelchair users. In addition, the student chose an elective course associated with a Leadership and Education in Neurodevelopmental Disabilities (LEND) program. This program includes exposure to community resources and instruction in how to advocate for children with disabilities and their families. Linking her service experiences, interest in children and engagement in occupation in the educational setting, the students' research project investigated children's perceptions of handwriting performance. As a result of compiling the literature related to the occupation of writing, the student discovered the importance of being able to use tools for self-expression, not only for handwriting but for engagement in art activities. Recognizing her passion for the arts, the student began to plan her EC. She applied the research literature related to the use of tools as part of expressive tasks, her service experiences, and her knowledge of educational policy to establish her EC. She completed her individualized EC through collaboration with an art teacher and occupational therapist in a private school for children with learning challenges. During this experience, she networked to modify the art curriculum, promoting engagement of children with special learning needs. She was able to actualize her individual values while expressing group values as she led a curricular revision at the school which benefited the children. Her EC reflected the crucial value of citizenship. On the student's EC evaluation, her community-based expert mentor indicated that the student's work made a positive difference in the clients served and the student demonstrated "professionalism, self-direction, and has been a joy to mentor" (Expert mentor, personal communication, May 2016)

\section{DISCUSSION AND IMPLICATIONS FOR OCCUPATIONAL THERAPY EDUCATION}

While the ACOTE Doctoral Standards (2011) require leadership as an outcome for entry-level doctorate programs, no specific details have been provided as to how to develop leadership skills. As entry-level education for the occupational therapist moves towards the doctorate, all programs will be required to identify how they are preparing students for leadership. Higher education has been challenged to "become engaged with its communities through actions and teaching" due to its unique position to "explore new ways of fulfilling the promise of justice and dignity for all...as part of the global community" (Hansen et al., 2007, p. 27). The AOTA Centennial Vision (AOTA, 2017) and Vision 2025 (AOTA, 2017 b) note the crucial need to develop occupational therapists as leaders; signaling to occupational therapy educators the responsibility to 
prepare future leaders of the profession. This responsibility requires using evidence to revise curricula to address the changing needs of the profession and society while aligning with the mission and vision of the program and academic institution. The SCM of leadership development is an emerging leadership paradigm that suggests leadership is a "purposeful, collaborative, values-based process that results in positive social change" (Dugan \& Komives, 2007, p. 9). The seven Core Values of the SCM are consistent with the core values and ethical principles of occupational therapy. Use of the SCM model provides a systematic, comprehensive, and evidenced-based model to guide leadership development as part of the occupational therapy curriculum.

Dugan et al. (2013) published the MSL Insight Report to share information on leadership outcomes using the SCM as a theoretical framework. They reported that it "isn't what we do but how we do it" that makes a difference in the developmental process of leadership in college students (p. 6). Based on their research, they provided recommendations regarding high impact practices including discussion about sociocultural issues, membership in off-campus organizations, mentoring, and community service. Guided service, with reflection and faculty advisement, affords students experiential learning opportunities to practice leadership skills, integrate social change values, and exercise knowledge learned in the classroom to a real world environment. This hands-on learning, according to Dewey (1938) and Kolb (1984) is thought to contribute to the overall development of the student, strengthen the understanding of educational concepts, and build civic engagement. As Dugan et al. (2013) suggest, quality and time of service are important. Quality service refers to interaction with the community instead of service for the community. Thus, occupational therapy educators are prompted to tailor community service experiences that cultivate interaction, collaboration, and the value of citizenship to meet system and community needs. For occupational therapists to be influential in "changing environments, policies, and complex systems" as directed in AOTA Vision 2025 (2017), attention is needed to be responsibly connected to the community and to work collaboratively with stakeholders to transcend system limitations. Although cultural responsiveness and awareness of disability and aging issues may be developed through service opportunities with marginalized populations (Whiteford \& St. Claire, 2002), mitigation measures to promote social and occupational justice may be better facilitated if leaders actualized individual, group, and society/community values associated with the SCM to promote positive social change. While the SCM may not fit with the mission of all entrylevel doctoral programs, all programs can identify outcome-oriented, evidence-based models for developing leadership skills.

Graduates must be capable of leading innovation in health care delivery given the factors impacting health care. WFOT Standards (2013) recommend "that $10-30 \%$ of an educational program should be focused on knowledge supporting an understanding of the human and social environment and social perspectives of health included within practice placements to integrate this knowledge and related skills and attitudes with practice" (p.46). An understanding of the human and social environment as well as social perspectives of health can also be appreciated through service-related experience. 
The doctoral program at Belmont University embeds service experiences and interactions with community partners throughout the curriculum based on high impact practices recommended by Dugan et al. (2013) to develop graduates who are equipped to actualize desirable social change. Although the program has received positive feedback from community stakeholders regarding students' ability to lead change, additional outcome measures are being analyzed including changes in SCM values over the course of the entry-level doctoral program. The program will be further exploring the impact of socio-cultural discussions on leadership development and is using tools to assess changes in students' implicit and explicit bias.

\section{References}

Accreditation Council for Occupational Therapy Education [ACOTE]. (2012). 2011 Accreditation Council for Occupational Therapy Education Standards. American Journal of Occupational Therapy, 66(6_Supplement), S6-S74. https://doi.org/10.5014/ajot.2012.66S6

ACOTE. (2017). ACOTE 2027 Mandate and FAQs. Retrieved from https://www.aota.org/Education-Careers/Accreditation/acote-doctoral-mandate2027.aspx

American Occupational Therapy Association. (2007). AOTA's Centennial Vision and Executive Summary. American Journal of Occupational Therapy, 61(6), 613-614. https://doi.org/10.5014/ajot.61.6.613

American Occupational Therapy Association. (2015). Occupational therapy code of ethics. American Journal of Occupational Therapy, 69, 6913410030p16913410030p8. https://doi:10.5014/ajot.2015.696S03

American Occupational Therapy Association. (2017b). Vision 2025. American Journal of Occupational Therapy, 71, https://doi.org/10.5014/ajot.2017.713002

Astin, W., \& Astin, A. (1996). A social change model of leadership development: Guidebook (Version III). Los Angeles: Higher Education Research Institute.

Belmont University School of occupational therapy (2014). Belmont University occupational therapy program mission statement. Retrieved from http://www.belmont.edu/ot/about/mission, vision and goals/index.html

Belmont University (2014). Belmont University mission statement. Retrieved from http://www.belmont.edu/about/mission.html

Boyer, E. (1990). Scholarship reconsidered: Priories of the professorate. Princeton, N.J: Carnegie Foundation for the Advancement of Teaching.

Caffarella, R., \& Daffron, S.R., (2013). Planning programs for adult learners (3 $3^{\text {rd }} \mathrm{ed}$.) San Francisco: Jossey-Bass.

Copolillo, A., Shepherd, J., Anzalone, M., \& Lane, S. (2010). Taking on the challenge of the Centennial Vision: Transforming passion for occupational therapy into a passion for leadership. Occupational Therapy in Health Care, 24(1), 7-22. https://doi.org/10.3109/07380570903304209

Corcoran, M. (2005). Leadership through scholarship in occupational therapy. American Journal of Occupational Therapy, 59, 607-608.

https://doi.org/10.5014/ajot.59.6.607

Dewey, J. (1938). Experience and education. New York: Simon and Schuster. 
Diamond, R. M. (2008). Designing and assessing courses and curricula: A practical guide ( $3^{\text {rd }}$ ed). San Francisco: Jossey Bass.

Dugan, J.P. (2006). Involvement and leadership: A descriptive analysis of socially responsible leadership. Journal of College Student Development, 47, 335-343.

Dugan, J., \& Komives, S. (2007). Developing leadership capacity in college students: Findings from a national study. A report from the Multi-Institutional Study of Leadership, College Park, MD: National Clearinghouse for Leadership Programs, $1-16$.

Dugan, J.P., Kodama, C., Correia, B. \& Associates. (2013). Multi-Institutional study of leadership insight report: Leadership program delivery. College Park, MD: National Clearinghouse for Leadership Programs, 1-29.

Dunbar, S.B., \& Winston, K. (2015). An occupational perspective on leadership Theoretical and practical dimensions (2nd ed.). Thorofare, NJ: SLACK.

Fidler, G. (1996). Developing a repertoire of professional behaviors. American Journal of Occupational Therapy, 50, 583-587. https://doi.org/10.5014/ajot.50.7.583

Gilfoyle, E. (1989). Leadership and occupational therapy. American Journal of Occupational Therapy, 43, 567-570. https://doi.org/10.5014/ajot.43.9.567

Gitlow, L., \& Flecky, K. (2005). Integrating disability studies concepts into occupational therapy education using service learning. American Journal of Occupational Therapy, 59, 546-553. https://doi.org/10.5014/ajot.59.5.546

Hansen, A.M., Muñoz, J., Crist, P.A., Ideishi, R.I., Primeau, L.A., \& Tupé, D. (2007). Service learning: Meaningful, community-centered professional skill development for occupational therapy students. Occupational Therapy in Health Care, 21,2549. https://doi.org/10.1080/J003v21n01 03

Higher Education Research Institute [HERI]. (1996). A social change model of leadership development (Version III). Los Angles: HERI.

lachini, A., Cross, T., \& Freedman, D. (2015). Leadership in social work education and the social change model of leadership. Social Work Education, 34. 650-665. https://doi.org/10.1080/02615479.2015.1025738

Kolb, D. A. (1984). Experiential learning: Experience as the source of learning and development. Englewood Cliffs, N.J.: Prentice-Hall.

Komives, S., Wagner, W., \& Associates. (2017). Leadership for a better world: Understanding the social change model of leadership development (2nd ed.). San Francisco: Jossey-Bass.

Mussleman, L. (2007). Achieving AOTA's centennial vision: The role of educators. Occupational Therapy in Health Care, 21, 1-2, 295-300. https://doi.org/10.1300/Joo3v21n01 29

Padilla, R. (2007). Educating leaders for the AOTA Centennial vision. Occupational Therapy in Health Care, 21, 305-307. https://doi.org/10.1300/J003v21n01 31

Peloquin, M. (2005). The 2005 Eleanor Clarke Slagle Lecture: Embracing our ethos: Reclaiming our heart. American Journal of Occupational Therapy, S9, 611-625. https://doi.org/doi:10.5014/ajot.59.6.611

Stetler, C., Ritchie, J., Rycroft-Malone, J., \& Charns, M. (2014). Leadership for evidence-based practice: Strategic and functional behaviors for institutionalizing EBP. Worldviews Evidence Based Nursing, 11, 219-226. 
Stoffel, V. (2013). From heartfelt leadership to compassionate care: Inaugural Presidential address. American Journal of Occupational Therapy, 67, 633-640. https://doi.org/10.5014/ajot.2013.676001

Tyler, R. W. (2013). Basic principles of curriculum and instruction. Chicago: University of Chicago Press.

Tyree, T.M. (1998). Designing an instrument to measure the socially responsible leadership using the social change model of leadership development. Dissertation Abstracts International, 59(06), 1945.

Wagner, W. (2006). The social change model of leadership: A brief overview. Concepts \& Connections, 15 (1), 9.

Whiteford, G., \& St-Clair, VW. (2002). Being prepared for diversity in practice: Occupational therapy students' perceptions of valuable intercultural learning experiences. British Journal of Occupational Therapy, 65(3), 129-137.

World Federation of Occupational Therapy [WFOT]. (2013). Minimum standards for the education of occupational therapist. Retrieved from http://www.wfot.org/store 


\section{Appendix A}

\section{Service and Scholarship Plan}

Student Name:

Faculty Advisor:

Advisement:

As a student in the School of Occupational Therapy Doctorate program, a faculty advisor will be assigned to assist the student through the educational program. Advisement topics will include student service, professional behaviors and academic performance. Students and faculty advisors will use the professional behaviors form and the service and scholarship plan form to guide the student in their professional, service and scholarly growth

\section{Service and Scholarship Plan}

A. To assist the student in identifying their personal service history, and identifying gaps for the purpose of planning their service hours for increased exposure to various populations

B. To enhance the students understanding of populations served by occupational therapists and the variety of roles or intervention types available to serve.

C. To assist the student in identifying areas of interest for scholarship. (for purposes of the Research and Experiential Component projects)

\begin{tabular}{|c|c|c|c|c|c|c|}
\hline Population & $\begin{array}{l}\text { Characteristics } \\
\mathrm{A}=\text { Able-Bodied } \\
\mathrm{PD}=\text { Physical } \\
\text { Disability } \\
\text { (consistency) } \\
\mathrm{MH}=\text { Mental } \\
\text { Health Disability } \\
\text { ID= Intellectual } \\
\text { Disability } \\
\\
{ }^{*} \text { Mark all that } \\
\text { apply }\end{array}$ & $\begin{array}{l}\text { Exposure } \\
\mathrm{L}=\text { limited } \\
\text { (less than } \\
40 \mathrm{hrs)} \\
\mathrm{F}=\text { Fair (40 } \\
-120 \mathrm{hrs)} \\
\text { E= } \\
\text { Extensive } \\
\text { (greater } \\
\text { than } 120 \\
\text { hrs) }\end{array}$ & $\begin{array}{l}\text { Context } \\
\mathrm{E}= \\
\text { Educational } \\
\text { setting } \\
\mathrm{C}=\text { Community } \\
\text { setting (home, } \\
\text { club or } \\
\text { program in } \\
\text { community) } \\
\mathrm{A}=\text { Agency } \\
\text { setting } \\
\mathrm{H}=\text { Heath care } \\
\text { setting } \\
\text { (hospital, clinic, } \\
\text { etc.) } \\
\\
\mathrm{G}=\text { Within } \\
\text { group } \\
\mathrm{I}=\text { Individual } \\
1: 1 \\
\\
\text { *Mark all that } \\
\text { apply }\end{array}$ & $\begin{array}{l}\text { Focus of Service } \\
\text { (caregiver, volunteer, } \\
\text { babysitter, group leader, } \\
\text { family member, advocate, } \\
\text { service provider, camp } \\
\text { counselor, educator, friend) }\end{array}$ & $\begin{array}{l}\text { Level of } \\
\text { Comfort } \\
1=\text { very } \\
\text { uncomfortable } \\
2=\text { somewhat } \\
\text { uncomfortable } \\
3=\text { neutral } \\
4=\text { somewhat } \\
\text { comfortable } \\
5=\text { very } \\
\text { comfortable }\end{array}$ & $\begin{array}{l}\text { Level of } \\
\text { Interest } \\
1=\text { not } \\
\text { interested } \\
2= \\
\text { interested } \\
3=\text { very } \\
\text { interested } \\
4=\text { not } \\
\text { sure }\end{array}$ \\
\hline $\begin{array}{l}\text { Infants (0- } \\
\text { 3yrs) }\end{array}$ & $\begin{array}{l}\text { A } \\
\text { PD }\end{array}$ & $\begin{array}{l}E \\
F\end{array}$ & $\begin{array}{l}C, I \\
C, G \& I\end{array}$ & $\begin{array}{l}\text { Babysitting, OT shadowing, } \\
\text { volunteering/research - Go } \\
\text { Baby Go }\end{array}$ & 5 & 3 \\
\hline
\end{tabular}




\begin{tabular}{|c|c|c|c|c|c|c|}
\hline $\begin{array}{l}\text { Young } \\
\text { Children } \\
\text { (4-12 yrs) }\end{array}$ & $\begin{array}{l}A \\
\text { ID }\end{array}$ & $\begin{array}{l}\mathrm{E} \\
\mathrm{F}\end{array}$ & $\mathrm{E}$ & $\begin{array}{l}\text { preschool teacher, } \\
\text { babysitting, } \\
\text { volunteering, research }\end{array}$ & 5 & 3 \\
\hline $\begin{array}{l}\text { Adolescents } \\
\text { and Young } \\
\text { Adults } \\
\text { (13-21 yrs) }\end{array}$ & ID & $\mathrm{L}$ & $C, G \& I$ & volunteering & 4 & 2 \\
\hline $\begin{array}{l}\text { Adults } \\
\text { (22-65 yrs) }\end{array}$ & $\begin{array}{l}\text { A } \\
\text { PD } \\
\text { ID }\end{array}$ & $\begin{array}{l}E \\
\mathrm{~L}\end{array}$ & $\begin{array}{l}\mathrm{H}, \mathrm{I} \\
\mathrm{H}, \mathrm{I}\end{array}$ & $\begin{array}{l}\text { OT shadowing } \\
\text { volunteering - Wheelcats } \\
\text { fieldwork - Waves, Inc. }\end{array}$ & 3 & 4 \\
\hline $\begin{array}{l}\text { Seniors } \\
\text { (over } 65 \text { yrs) }\end{array}$ & ID \& PD & $\mathrm{F}$ & $A, G$ & $\begin{array}{l}\text { volunteering - FiftyForward } \\
\text { fieldwork - Waves, Inc. }\end{array}$ & 3 & 1 \\
\hline
\end{tabular}

